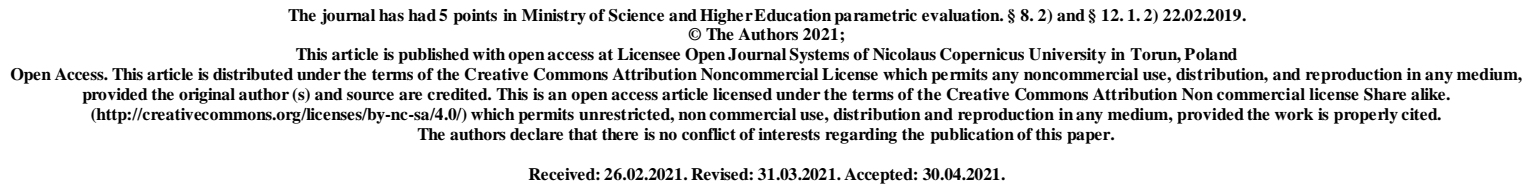

UDK 272 (477.83) “1958/1964"

\title{
SPECIAL FEATURES OF CONFESSIONAL LIFE OF THE ROMAN CATHOLIC CHURCH IN THE WESTERN REGIONS OF UKRAINE IN 1958-1964
}

\section{Taras Didukh}

\section{Ternopil Volodymyr Hnatiuk National Pedagogical University}

M. Kryvonosa Str., bld. 2, city Ternopil, Ukraine, 46027 diduchtaras@ukr.net

ORCID 0000-0002-4834-4369

\section{Abstract}

The influence of the anti-religious campaign of the Soviet government on confessional life of the Roman Catholic Church is examined in the article, based on the study of special literature and involvement and complex analysis of the archival sources. Changes that took place in the Roman Catholic denomination due to pressure of the Soviet authorities on it, in particular reduction of its network in the western regions of Ukraine in 1958-1964, are analyzed.

Key words: Roman Catholic Church; Roman Catholic clergy; state and church relations; confessional life; anti-religious campaign.

\section{Formulation of the problem}

An important place in modern historical science is occupied by studies of the policy of the Soviet government towards the Roman Catholic Church. The main focus is put on the 
problems that have national and international context. The regional features of the Roman Catholics' confessional life and the attitude of local authorities to them remain insufficiently studied. The problem of the relationship between the Soviet authorities and Roman Catholics in 1958-1964 deserves special attention. In this context, it is important to trace the impact of anti-religious campaign of the Soviet government on the confessional life of the Roman Catholic Church, in particular, reduction of its network in the western regions of Ukraine in 1958-1964.

Analysis of recent studies and publications. The problem of the Soviet government's policy towards the Roman Catholic Church during the anti-religious campaign conducted by the Soviet authorities led by M.Khrushchov remains the little-studied. Some aspects of this problem were studied by E. Bystrytska [3; 4], V. Voinalovych [5], V. Baidych [2] and others. In their work, the scholars have focused on the political component of these relations, but have not considered their local, territorial differences.

I. Andrukhiv [1], V. Sergiichuk [28], Ya. Stotskyi [29] and A. Morenchuk [27] have studied position of the Roman Catholic Church in the western regions of Ukraine during the rule of Khrushchov more comprehensively. However, a number of aspects in the activities of the Roman Catholic Church in the western regions of Ukraine during the anti-religious campaign of the Soviet government still need detailed research.

The goal of the scientific work is comprehensive coverage and analysis of the confessional life of the Roman Catholic Church in the western regions of Ukraine during the anti-religious campaign (1958-1964). Achieving the goal of the study involves solving the following tasks: to highlight situation of the Roman Catholic Church in the western regions of Ukraine and to analyze the measures taken by the Soviet authorities to limit its activities.

Statement of basic materials. In the late 1950s and first half of the 1960s, the position of the Roman Catholic Church deteriorated as a result of anti-religious campaign, as the authorities used administrative measures to reduce the number of functioning religious communities and priests in their fight against Roman Catholics.

In general, during 1958, the process of reducing the number of officially registered Roman Catholic communities and priests intensified significantly. As of January 1, there were 170 communities in Ukraine, with 89600 believers and 72 Roman Catholic priests (hereinafter - the priest(s) providing spiritual care. At the end of the year, the number of registered communities decreased to 167 , and the number of priests by 16 persons [30, p. 60; 31, p. 156]. The largest reduction in the number of registered priests took place in the western regions of Ukraine. The total number of officially registered priests, who remained in their 
parishes in the regions in 1958 was the following: Drogobych - 5, Lviv - 5, Stanislav - 1, Ternopil - 4. In total, only 15 priests remained in these regions for 36 communities [12, p. $119 ; 13$, p. $32 ; 7$, p. $2 ; 18$, p. 122$]$.

With the Decree of the Presidium of Verkhovna Rada of the Ukrainian SSR nr. 111 of May 21, 1959, Drogobych Region was liquidated and its territory was included into Lviv Region. These administrative changes affected the reporting documents, in particular in the field of religious organizations in Lviv Region. As of June 1 of that year there were 24 officially registered Roman Catholic communities in Lviv Region, with only 7 priests, providing spiritual services. We should emphasize that there were 18 functioning Polish Roman Catholic churches (hereinafter - the church(es) in these 24 communities, but only in 6 worships were held regularly. Permanent churches, spiritual service in which was provided by the priests at their place of residence, were located in Lviv - the Roman Catholic Cathedral of the Assumption of the Blessed Virgin Mary (priests K. Yaschemskyi and L. Severyn), church of the St. Anthony of Padua (priest I. Khvirut) and of the St. Mary Magdalene (priest Z. Galunevych); in the town Zolochiv (priest Ya. Tsenskyi); town Mostyska (priest Ye. Saletnyk); village New Misto of Dobromyl District (priest I. Shatelya). In the catholic churches of the towns Bibrka, Gorodok, Dobromyl, Zhydachiv, Sambir, Stryi, townships Pomoriany (Zolochiv District), Shchyrets (Pustomyty District) and the villages Dunaiv (Zolochiv District), Lanovychi (Sambir District), Mizhenets (Nyzhankovychi District), Novosilky (Glyniany District) due to the lack of priests worship and religious rites for the believers were performed by the mentioned priests only a few times a year. Instead, the churches did not act in 6 Roman Catholic communities, which were located in the villages Balychi, Lypnyky, Myshliatychi, Pnikut, Tshchenets, Mostyska and Strilkovychi of Sambir District because of the lack of priests. The total number of believers in these communities, according to official data, was about 13 thousand people [13, p. 205-207, 288].

Thus, there was a significant disparity in the number of registered communities and priests, as only 6 communities had abbots. At the same time, the authorities continued to pursue a policy of gradually reducing the number of officially registered Roman Catholic communities. Based on the decision of the Council for Religious Cults at the Council of Ministers of the Soviet Union of April 9, 1959, the communities of the villages Chukva and Biskovychi of Sambir District were deregistered [13, p. 207].

It should be noted that according to M. Dril, the commissioner of the Council for Religious Cults, there were approximately 13 thousand believers in 24 functioning Roman Catholic communities. In our opinion, the official statistics is to be clarified, because 
according to the All-Union census as of December 1, 1959, 57979 persons of Polish nationality lived in Lviv Region. We understand that most of these citizens were Roman Catholics. But, apparently, M. Dril deliberately underestimated the true number of believers in the registered communities in order to create formal grounds for their further deregistration $[13$, p. $288 ; 14$, p. 8$]$.

In 1960, the number of officially registered communities of Roman Catholic Church in Lviv Region did not change compared to the previous year, there were 24 of them. The total number of believers in these communities was about 13 thousand people, whose spiritual care was provided by 7 priests [14, p. 175-178].

That year, M. Dril made efforts to implement the provisions of the resolution of the Central Committee of the Communist Party of the Soviet Union of January 13, 1960 "On measures to eliminate violations of the Soviet legislation on cults by the clergy". As a result of administrative restrictions by the commissioner and local authorities, the number of visits of the registered priests to the communities without an abbot has halved to 1-2 times a year. In addition, in order to reduce the religious activity of Roman Catholics in Lviv, M. Dril removed from the service in the Cathedral of the Assumption of the Blessed Virgin Mary padre L. Severyn, leaving him the abbot of the church in the township Shchyrets of Pustomyty District. The commissioner registered padre Z. Galunevych, the new rector of the cathedral leaving him to serve in the church of the St. Mary Magdalene. Due to the respectable age (73 years old) and the state of health padre Z. Galunevych could not fully serve both churches, so the priest conducted daily services in the Cathedral, and in the church of the St. Mary Magdalene only on Saturday nights and Sunday mornings, and not always. Thus, the number of services held in the church of the St. Mary Magdalene, because the priest could not physically provide regular spiritual care to all his parishioners [14, p. 55-56, 183]. By similar methods M. Dril tried to reduce attendance in the existing temples in order to further deregister them.

As of July 1, 1959, only two officially registered Roman Catholic communities remained in Stanislav Region in the towns of Stanislav and Bolekhiv, served by padre Ya. Pavilianis. It should be noted that the community of Bolekhiv was under threat of deregistration. Thus, on May 30, 1958, the commissioner of the Council for Religious Cults I. Vizirenko arranged an inspection of the activities of this community and found that due to the departure of Polish believers to Poland for permanent residence, 7 persons were missing the "church twenty". Upon discovering this fact, the commissioner obliged the community to supplement the composition of the Roman Catholic Church council. The Roman Catholic 
Church council and the audit commission were re-elected, but I. Vizirenko "decided" that reelections took place with violations. Based on this, the commissioner, together with the chairman of the executive committee of Bolekhiv District Council, Lendei, conducted a reinspection of the community on August 22-23. At the same time, local authorities worked with newly elected members of the Roman Catholic Church council, forcing them to resign. As a result of pressure from the authorities, six members of the Roman Catholic Church council refused to run in the by-elections and found their signatures on the documents to be false. Using the refusal of members of the Roman Catholic Church council to participate in the elections, as well as the fact that almost half of the believers, who attended the church were Greek Catholics, I. Vizirenko "decided" that the Roman Catholic community of Bolekhiv to be disintegrated [6, p. 55-57; 7, p. 2].

On the basis of absence of the priest in the community of Bolekhiv and the formal disintegration of the "church twenty", at the request of the regional executive committee, the commissioner appealed to the Council for Religious Cults at the Council of Ministers of the Soviet Union to deregister the community. Consideration of this issue in various government agencies lasted almost a year. During this time the church was closed. Only on December 19, 1959 the Council for Religious Cults at the Council of Ministers of the Soviet Union approved the decision of Stanislav Regional Executive Committee of October 7, 1959 on deregistration of the Roman Catholic community of the town Bolekhiv and transfer of the church to Bolekhiv secondary school nr. 1 for further conversion into a gym $[6$, p. 85; 9, p. 39].

Thus, there is only one functioning church left in the region in the city Stanislav, served by padre Ya. Pavilianis. It should be noted that the new commissioner of the Council for Religious Cults at Stanislav Regional Executive Committee I. Ruban, who replaced I. Vizirenko in this position on August 8, 1959, sought to close the last functioning church. To do this, he carefully analyzed the state of the community in Stanislav and found that the church was regularly visited mainly by Greek Catholics (approximately 50-80 people), and Roman Catholics there were only 20-30 people, mostly elderly one. In addition, the executive body of the community did not act in full for more than a year, as believers under pressure of the authorities refused to elect, what padre Ya. Pavilianis repeatedly received warnings from the commissioner for. Each time the priest promised to replenish it, but due to the actions of the authorities he failed to do this [7, p. 11; 9, p. 38-39].

It should be noted that the church of the Blessed Virgin Mary in Stanislav as a historical monument was in a state of disrepair, and the city authorities had no intention to 
repair it. In early 1959, the believers decided to repair the church at their own expense and began raising funds among members of the community (raised more than 3 thousand rubles). Upon learning this, the commissioner accused padre Ya. Pavilianis in violation of Soviet legislation on religious cults and deregistered him. In addition, KGB officers became interested in the priest's activities. At the same time, the Construction and Architecture Department at the Regional Executive Committee, which had the church on its balance sheet, filed a lawsuit against the community, accusing it of failing to repair the church since its use, causing "significant damage" to the building. The plaintiff demanded to collect from the community 442301 rubles 99 kopecks, i.e. the full cost of future major repairs. The trial, which took place over the Stanislav Roman Catholic Church community on February 19, 1960, did not satisfy the plaintiff's request, but only fined padre Ya. Pavilianis on 3000 rubles. On June 21, 1960, in agreement with the Council for Religious Cults at the Council of Ministers of the Ukrainian SSR, the last functioning Roman Catholic community in the city Stanislav was deregistered despite the fact that more than 3,000 Polish nationals lived in the region [1, p. 96-97].

At the end of 1960, there were no officially registered Roman Catholic communities in Stanislav Region. It should be noted that padre Ya. Pavilianis, deregistered by the commissioner, continued to worship and perform religious rites in the homes of both Roman Catholics and Greek Catholics in secret. Upon learning this, I. Ruban summoned the priest to reception and warned that if he continued his priestly activity, he would be prosecuted. Therefore, to avoid repression by the authorities, padre Ya. Pavilianis was forced to leave the region [8, p. 12]. After leaving of the priest from Stanislav Region, the Roman Catholic Church was underground for almost thirty years.

In 1959, there were 1555 Roman Catholics living in Ternopil Region, namely, 513 men $(33 \%)$ and 1042 women (67\%); young people under 25 years old made 196 people (12.6\%). These data indicate a sharp decline in the number of Catholics in the region. After all, during 1958, 171 people left Ternopil Region, namely 122 people moved to Poland, 32 people died, 10 people went to work, 6 people were enlisted in the army and 1 person went to study. In just 4 years (1955-1958), 825 Roman Catholics left the region [18, p. 123-124].

That year, 8 officially registered churches continued to operate in Ternopil Region, serving by 4 priests. Ya. Matsyshyn lived in Kremenets and served 3 churches: in the town Kremenets, township Pidvolochysk and village Galushchyntsi; Yu. Adamchyk lived in Borshchiv and served 2 churches: in the town Borshchiv and village Losiach; K. Feishaker lived in the village Khomiakivka and served 2 churches: in the villages Khomiakivka and 
Rydoduby; S. Vychysanyi lived in the village Korolivka and served church in the village Korolivka [18, p. 122].

As of January 1, 1960, there were still 8 registered Roman Catholic communities in Ternopil Region, but as a result of the administrative-territorial reform, there were some changes in their names and locations. In general, location of communities and the number of believers in them was the following: in town Borshchiv - 137 persons; village Korolivka of Borshchiv District - 98 persons; village Losyach of Borshchiv District - 117 persons; town Kremenets - 206 persons; town Pidvolochysk - 210 persons; village Galushchyntsi of Skalat District - 256 persons, village Kosiv (as a result of administrative-territorial reform, village Khomiakivka became a part of Kosiv village council as a hamlet - Ternopil State Archives) of Chortkiv District - 197 persons; village Rydoduby of Chortkiv District - 332 persons. The total number of all believers was 1553 people [24, p. 4].

During the year significant changes took place among the Roman Catholic communities and the clergy. In accordance with government regulations, commissioner of the Council for Religious Cults used all the circumstances that limited the activities of Roman Catholic Church. Since the abbots of the church died in the village Korolivka of Borshchiv District, namely the priest S. Vychysanyi (December 28, 1959), and on April 12, 1960 - K. Feishaker, who served in the villages Khomiakivka and Rydoduby the churches, named temples, except Rydoduby church, were closed. Thus, the Council for Religious Cults at the Council of Ministers of the Soviet Union on June 28, 1960 deregistered the Roman Catholic community in the village Korolivka, and its church passed to Borshchiv District Executive Committee [20, p. 79].

Similar situation has developed with the church in the village Kosiv of Chortkiv District, which on August 13, 1960 was deregistered with the decision of the Regional Executive Committee on the basis of "self-dissolution" of the religious community and "refusal of twenty" to pay future taxes for the church [19, p. 88]. Undoubtedly, the main reason for deregistering the churches was ideological confrontation between the Soviet authorities and Roman Catholic Church. It should be noted that the Roman Catholic denomination operated legally at the territory of the Soviet Union, its believers and clergy complied with Soviet legislation on cults, so the means of pressure on Roman Catholics were limited. However, the authorities used various methods to close the churches, in particular, after the death of the priest, another priest was not allowed into the parish, and the church and community were deregistered for various reasons. 
Thus, at the end of 1960 there were only 6 functioning churches in Ternopil Region, which numbered 1258 believers, namely: in the town Borshchiv - 137 persons; village Losiach of Borshchiv District - 117 persons; town Kremenets - 206 persons; township Pidvolochysk - 210 persons; village Galushchyntsi of Skalat District - 256 persons; village Rydoduby of Chortkiv District - 332 persons. These churches were served only by two Roman Catholic priests: padre Yu. Adamchyk (Borshchiv, Losiach, Rydoduby) and padre Ya. Matsyshyn (Kremenets, Pidvolochysk, Galushchyntsi) [23, p. 2].

But in addition to these 6 officially registered Roman Catholic communities, there were 9 other unregistered ones in the region with a total of 722 believers. The location and number of members in these communities were the following: in Skalat - 300; Polupanivka and Staryi Skalat of Skalat District - 100; Kosiv of Chortkiv District - 69; Ternopil - 63; Dorofiivka of Pidvolochysk District - 60; Semakivtsi of Chortkiv District - 55; Korolivka of Borshchiv District - 44; Zbarazh - 20; Shumsk - 11 Roman Catholic believers [23, p. 2-3]. In total, there were 1980 believers of the Roman Catholic Church in the region.

At the beginning of 1961, there were 24 officially registered Roman Catholic communities in Lviv Region, the spiritual service of which was provided by 7 priests [10, p. $175 ; 15$, p. 107].

That year, the believers of the town Sambir twice appealed to the authorities to invite padre Ya. Pavilianis to their parish for permanent service. Commissioner M.Dril, having received permission from the heads of the Council for Religious Cults at the Council of Ministers of the Ukrainian SSR, registered padre Ya. Pavilianis as the abbot of Sambir church. As a result, the number of officially registered priests in the region increased to 8 persons $[16$, p. 30]. It should be noted that despite the above concession to the believers by the authorities, the administrative pressure on Roman Catholic Church increased during the year.

As of January 1, 1962, there were already 8 officially registered priests living in Lviv Region, but the number of functioning communities decreased to 23, as in the second half of 1961 the commissioner deregistered the community in the village Strilkovychi of Sambir District. In addition, at the beginning of 1962, M. Dril, at the request of Mostyska District Executive Committee, deregistered the Roman Catholic communities in the villages Balychi, Myshliatychi, and Tshchenets as "disintegrating themselves". The total number of believers in these communities, according to official data, was about 12 thousand people, about 8.5 thousand people of whom regularly attended the churches during the major religious holidays 
[16, p. 28-36, 102-103]. By nationality, almost 90\% of believers, who attended the functioning churches were Poles, and 10\% - Ukrainian Greek Catholics [16, p. 171].

The regional commissioner of the Council for Religious Cults considered the issue of "legal" deregistration of Roman Catholic communities also in the city Lviv (church of the St. Mary Magdalene), town Gorodok, township Pomoryany of Zolochiv District, village Novosilky of Glyniany District and village Lypnyky of Mostyska District. In addition, for violating the law on religious cults and missionary work among believers, M. Dril deregistered the Executive Committee and the Audit Commission of the community of the town Sambir and issued a warning to the Executive Committee of the church of the St. Anthony of Padua in the city Lviv [16, p. 102-103].

At the beginning of 1963, there were only 16 officially registered Roman Catholic communities in Lviv Region, because in the second half of 1962, the commissioner of the Council for Religious Cults, at the request of the local authorities, deregistered the community of the St. Mary Magdalene in the city Lviv, town Bibrka, villages Lipnyky of Mostyska District and Lanovychi of Drogobych District. Spiritual care for the existing communities continued to be provided by 8 priests [17, p. 12-16].

During the current year, following the orders of the party-state leaders to reduce the number of officially registered Roman Catholic communities in Lviv Region, the new commissioner of the Council for Religious Cults in Lviv Region M. Savichev deregistered the community in the town Zhydachiv, villages Mizhenets of Staryi Sambir District and Novosilky of Zolochiv District. As a result of the Commissioner's actions, only 13 functioning Roman Catholic communities remained in the region [17, p. 110].

In 1964, there were 13 registered Roman Catholic communities in Lviv Region, only 7 of which had abbots. Permanently functioning churches, which spiritual service was provided by the priests at their place of residence, were located in the city Lviv -Cathedral of the Assumption of the Blessed Virgin Mary (priests K. Yashchemskyi and Z. Galunevych), church of the St. Anthony of Padua (priest I. Khvirut); in the towns Zolochiv (priest Ya. Tsenskyi); Sambir (priest Ya. Pavilianis); Mostyska (priest Ye. Saletnyk); township Shchyrets of Pustomyty District (priest L. Severyn); village Nove Misto of Dobromyl District (priest I. Shatelia). Instead, in 6 Roman Catholic communities (towns Dobromyl, Gorodok, Stryi, township Pomoriany of Zolochiv District, village Dunaiv of Peremyshliany District, village Pnikut of Mostyska District), which did not have a priest, believers gathered independently in the churches and conducted worship [11, p. 64-68]. 
In Ternopil Region during 1960 there were some changes in the number of communities as a result of reducing the number of believers of the Roman Catholic Church. As of January 1, 1961, according to official statistics, there were 1257 Catholics in 6 registered Roman Catholic communities in Ternopil Region, including 441 men (35\%), 816 women (65\%), and 112 young people under the age of 25 (9\%) [24, p. 4].

It should be noted that during 1961-1963 the number of Roman Catholic Church communities in Ternopil Region remained unchanged - there were 6. However, the number of believers in them was constantly declining. As of January 1, 1961, there were 1230 persons living in the region, as of January 1, 1962, 1200 persons, and as of January 1, 1963, the number of believers was 1030, which is 200 believers (16\%) less than in 1961 [25, p. 4-5].

As of January 1, 1963, there were 6 officially registered Roman Catholic communities in Ternopil Region with the following number of believers: in the town Borshchiv - 130 persons; village Losiach of Borshchiv District - 110 persons; village Rydoduby of Chortkiv District - 160 persons; town Kremenets - 200 persons; township Pidvolochysk - 200 persons; village Galushchyntsi of Pidvolochysk District - 230 persons. The total number of all believers was 1030 persons [21, p. 8-9].

Until 1963 these communities were served by two Roman Catholic priests: padre Ya. Matsyshyn and padre Yu. Adamchyk. After the death of padre Yu. Adamchyk (in June 1963) there was only one priest left in 6 Roman Catholic communities - padre Ya. Matsyshyn. As he was unable to worship by himself in all the churches, the number of liturgies decreased significantly. Worship services were held regularly only in the church in the town Kremenets, where the priest lived, and in the churches of the town Borshchiv and village Galushchyntsi services were held once every one or two months [26, p. 13-14].

Under the pretext of the emergency condition of the church in Pidvolochysk was withdrawn from the community. During 1963, the believers of Pidvolochysk community repeatedly appealed to Verkhovna Rada of the Soviet Union, Council of Ministers of the Soviet Union and the Council for Religious Cults at the Council of Ministers of the Soviet Union to allow them to carry out major repairs of the temple seized by the local authorities and to hold services there. But they were denied on the grounds that the church was in a state of disrepair and was to be demolished due to the reconstruction of the district center. Believers were advised to visit the temple in the village Galushchyntsi, Pidvolochysk District [26, p. 13-14, 36].

In general, as a result of the anti-religious campaign on the territory of Ukraine as of 1964, only 100 officially registered communities of the Roman Catholic Church remained in 
8 regions, in which there were approximately 60500 believers [2, p. 296; 27, p. 131]. Of these, only 13 communities worked in Lviv Region, 6 in Ternopil Region, and no functioning Roman Catholic community remained in Ivano-Frankivsk Region [11, p. 64-68; 22, p. 1].

\section{Conclusions}

Thus, as a result of anti-religious campaign carried out during 1958-1964 by the top Soviet state and party leadership led by M. Khrushchov, the confessional network of the Roman Catholic Church in the Western Regions of Ukraine was significantly reduced. State pressure on the Roman Catholic Church during this period led not only to significant material losses of the Church, but also to a certain weakening of the influence of the Roman Catholic clergy on the believers through large-scale administrative pressure and increased atheistic propaganda. However, thanks to the strong religiosity and unity around the clergy, the Roman Catholics managed to withstand persecution, defend at least part of the network of functioning communities and continue to work to preserve their religion in the Soviet totalitarian system.

\section{References}

1. Andrukhiv I.O. Liquidation of religious communities and the monasteries of the Roman Catholic Church in Stanislav Region in 1944-1960 / Andrukhiv I.O. // Skhid. 2008. nr. 4 (88). P. 93-97.

2. Baidych V.G. Anti-religious campaign of Soviet authorities in 1958-1964 and the Roman Catholic Church in Ukraine / Baidych V.G. // Scientific notes of Ivan Fedorovych Kuras Institute for Political and Ethno-National Studies of the National Academy of Sciences of Ukraine. K.: Lysenko M.M., 2010. V. 2. P. 295-309.

3. Bystrytska E.V. Evolution of the policy of the Soviet authorities on the Roman Catholic and Greek Catholic churches in 1939-1948. // Scientific notes [National University Ostrog Academy]. Series: Historical Religious Studies. 2011. Issue 4. P. 32-41.

4. Bystrytska E.V. Eastern policy of the Vatican in the context of the Holy See's relations with Russia and the Soviet Union (1878-1964): Monograph. Ternopil: Pidruchnyky \& Posibnyky, 2009, 416 p.

5. Voinalovych V.A. Party-state policy on religion and religious institutions in Ukraine in 1940-1960: political science discourse / Voinalovych V.A. K.: Svitogliad, 2005. $741 \mathrm{p}$.

6. State Archives of Ivano-Frankivsk Region. F. R. 388. Desc. 2. Ref. 55.86 p.

7. State Archives of Ivano-Frankivsk Region. F. R. 388. Desc. 2. Ref. 89.17 p.

8. State Archives of Ivano-Frankivsk Region. F. R. 388. Desc. 2. Ref. 91.54 p.

9. State Archives of Ivano-Frankivsk Region. F. R. 388. Desc. 2. Ref. 93.95 p. 
10. State Archives of Lviv Region. F. P. 3. Desc. 8. Ref. 266. 208 p.

11. State Archives of Lviv Region. F. P. 3. Desc. 9. Ref. 85. 133 p.

12. State Archives of Lviv Region. F. P. 5001. Desc. 33. Ref. 54. 130 p.

13. State Archives of Lviv Region. F. R. 1332. Desc. 2. Ref. 27. 295 p.

14. State Archives of Lviv Region. F. R. 1332. Desc. 2. Ref. 28. 223 p.

15. State Archives of Lviv Region. F. R. 1332. Desc. 2. Ref. 30. 174 p.

16. State Archives of Lviv Region. F. R. 1332. Desc. 2. Ref. 31. 233 p.

17. State Archives of Lviv Region. F. R. 1332. Desc. 2. Ref. 33. 181 p.

18. State Archives of Ternopil Region. F. P. 1. Desc. 1. Ref. 3125. 174 p.

19. State Archives of Ternopil Region. F. P. 1. Desc. 1. Ref. 3325. 184 p.

20. State Archives of Ternopil Region. F. R. 3239. Desc. 1. Ref. 28. 82 p.

21. State Archives of Ternopil Region. F. R. 3239. Desc. 1. Ref. 37. 20 p.

22. State Archives of Ternopil Region. F. R. 3239. Desc. 1. Ref. 42. 20 p.

23. State Archives of Ternopil Region. F. R. 3239. Desc. 2. Ref. 52. 13 p.

24. State Archives of Ternopil region. F. R. 3239. Desc. 2. Ref. 53.55 p.

25. State Archives of Ternopil Region. F. R. 3239. Desc. 2. Ref. 62. 41 p.

26. State Archives of Ternopil Region. F. R. 3239. Desc. 2. Ref. 67. 50 p.

27. Morenchuk A.A. Church and religious life in Ukraine in 1953-1964 (on the materials of the western regions): Monograph / Morenchuk A/A. Lutsk: Volyn. Lesya Ukrainka National University, 2009. 196 p.

28. Sergiichuk V.I. In the struggle for the native faith, Roman Catholics of Ukraine have always been steadfast / Sergiichuk V.I. K.: Dnipro, 2001. 228 p.

29. Stotskyi Ya.V. State and religion in the western regions of Ukraine: confessional transformations in the context of state policy in 1944-1964: [Monograph] / Stotskyi Ya.V. K.: FADA, LTD, 2008. 510 p.

30. The Central State Archive of Public Associations of Ukraine. F. 1. Desc. 24. Ref. 4704. $425 \mathrm{p}$.

31. The Central State Archive of Public Associations of Ukraine. F. 1. Desc. 24. Ref. 4927. $328 \mathrm{p}$. 